posed the benzene formula, Japp delivered a memorial lecture in England in which he says:

"Kekulé's work stands preëminently as an example of the power of ideas. A formula, consisting of a few symbols jotted down on paper and joined together by lines, has supplied work and inspiration for scientific organic chemists during an entire generation, and has afforded guidance to the most complex industry that the world has ever seen."

If you will agree with me that my arguments are sound, then it must follow logically that the new laboratory, which has been entrusted to me and to my staff, to-day, can render greater service to the community and at the same time advance the science of chemistry best, if it is so organized as to deny, absolutely, that there exists between theory and practice even so much as a discernible cleavage plane. For the well-being of both they must be wedded-they must take one another for better or for worse.

The consequences of this point of view are almost self-evident. It will be our duty to see to it that elementary students who take courses in chemistry shall receive a most thorough training in the fundamental facts and laws of modern chemistry. As the students advance, their individual preferences will require different outlets for their activities, but, in any event, the department must see to it that each one shall develop along the lines which are best suited to make him an independent thinker and producer in the fields of chemistry.

So, for the advanced students, we should encourage in some the pursuit of research which may be as abstract as he pleases to make it, while in other cases it may be intimately associated with the noise and clangor of industry, believing, at all times, that both pathways lead ultimately to the same goal, the advancement of the noble science of chemistry, as well as the happiness, prosperity and well-being of mankind.

\section{REPLY ON BEHALF OF THE AMERICAN CHEMICAL SOCIETY}

By JOHN URI LLOYD

One of my friends said to me, "Now, Lloyd, Professor Herty is going to tell us about 'The Swing of the Pendulum,' which subject takes in all there is in chemistry, so you won't have anything to say about chemistry. Then Professor Jones is going to give us the history of the Chemical Society in Cincinnati, and it will be well for you not to take up much time talking about that." "What am I to talk about?" "Well," said he, "it is to be expected that an old man will talk about the early days, and give incidents that the younger people haven't had an opportunity to hear about, connecting times gone by with the present." So I shall take my text from the following thought, "Remember now thy Creator in the days of thy youth," and aim to put what I have to say within the fifteen minutes given me.

I speak as one who looks back, before there was any University of Cincinnati, before there was even a systematic "Art" of Chemistry in Cincinnati. I remember when the study of chemistry was started here, and believe I know the "Creator" of it all. As I cast my mind back into those days, 1863-4, come to mind those known then as the chemists of Cincinnati. They were Edward S. Wayne, Chemist of the Ohio College of Medicine, Daniel Vaughan of the Eclectic Medical College, and Professor Adolph Fennell, father of Professor C. T. P. Fennell. This was before the Cincinnati College of Pharmacy was established. Dr. J. F. Judge, Dr. W. B. Chapman, and others were co-laborers on the staff that followed. There were also the chemists of the public schools, one of whom you will remember as Professor Stuntz. In those days, the chemist was expected to be a druggist or a teacher in a school. Nothing was there such as we now have in professional chemistry. And yet the principles that dominated pharmacy and chemistry fifty years ago gave birth to the broader vision of the chemist of the present.

Dr. W. B. Chapman, who established himself as apothecary at 6 th and Vine, where the Weatherhead drug store now stands, was one of the educated pharmacists in Cincinnati. There were but a few of these, the pharmacists of those days having, as a rule, undergone a very heroic apprenticeship. I can in my mind's eye see Dr. Chapman now. Well did he serve the people of Cincinnati. And with such an ideal before me, I think next of Professor Adolph Fennell, father of our present Professor Fennell, of the College of Pharmacy to-day. Many here cannot but remember him, kindly as a child, a talented, educated, German pharmacist-chemist, a good citizen, a man who did much in the beginning as a creator of that which followed. Comes now to view Daniel Vaughan, that man of extensive learning, who came down the Pike from Lexington, Kentucky, walking to Cincinnati, as also did Rafinesque, the botanistscientist. Vaughan did what he could in behalf of chemistry, and, at the last he quietly starved and died in a little upstairs corner room at Sixth and John Streets, thus paralleling, in death as in life, the life of Rafinesque, for Professor C. S. R. Rafinesque died a pauper in the rich city of Philadelphia, his body being dissected as that of a homeless vagrant. The room where Vaughan died stands yet at Sixth and John Streets. Vaughan, recognized the world over as a great scientist and mathematician, it is true, starved to death in Cincinnati, but this was his own fault, because he was too proud to beg, too rich in intellectuality to consider physical pain. These men, and such as they, gave to us the chance that comes to us of Cincinnati to-day. Had it not been for them, there could have been no University at the date it was founded, such as stands on this beautiful hillside to-day. Their inspiration gave us Hanna Hall, and the inspiration of which they were a part, gave us that which followed Hanna Hall. Where we stand to-day was then country, only. Burnet Woods had not even been made a part of the city. Indeed, as I recall events, it was long a question whether Cincinnati would receive it as a gift. Fortunately, it was accepted.

Whatever is, had a beginning, but few realize how slight is that beginning. Like the seed from which grew the great redwood tree of the West, was the beginning of this great building here. Its beginning is the very commencement of cosmopolitan art, of alchemistic chemistry, and of connected sciences, which are one and all lost in the shadows of antiquity.

After the days of Chapman and Fennell and Wayne and Judge and Vaughan, those pioneers of the olden time, came the founding of the society that I am honored in representing today. The old building in which this start was formulated stands to-day down the hillside, pathetically pleading its own cause. I remember the problems with which McMicken University on the hillside then had to contend. She had no professor of chemistry. The public schools of Cincinnati gave to her the first teacher of chemistry. Give credit to Professor Stuntz, of Hughes High School, whose lectures were given, not in a grand edifice like this, but in the very basement of that old building to a class numbering a possible dozen.

The first authorized Professor of Chemistry in the Cincinnati University, was F. W. Clarke. But partly understood by the men among whom he moved, a pure scientist, his ideals were in investigating lines, not then conceived to be connected with commercial activity. For this reason he did not appeal to most people, but some, like myself, felt like taking off our hats when we met him. Professor F. W. Clarke was working on what he knew to be the very foundation of chemistry, but yet this was seemingly outside the lines of bread and butter, as chemistry was then looked upon. 
Came then Professor Thomas H. Norton, and came soon an inprovement in location in the building. He was given a much better place than down in the basement. Chemistry was no longer considered a spectacular study, for exhibition purposes as a lecture rom show, a something with which to entertain children. Chemistry had now come to be viewed as a science destined to become a feature of the future, and to dominate every-day life. Professor Norton was a man well qualified to utilize chemistry for practical purposes. With him, by good fortune, came Mr. Hanna's gift, Hanna Hall. At that time I was very close to Norton. I knew what he was strugging to accomplish, and time and again spent afternoons and Sundays in his home when the new chemical department was being planned I compretend what he and Mrs. Norton did to found that de-

- partment. Together they made charts for atomic and molecular weights. Together they worked on models to exhibit problems in stereo-chemistry. In other ways Mrs. Norton helped, preparing demonstration maps for chemical lectures explanatory of experments. Professor Norton and his assistants had little in the way of apparatus, but with that little and what they added, they did well their work. Then came the call room, look at that old laboratory in Hanna Hall, then consider this. View the apparatus in the great building constructed for chemistry, only. Dr. Jones sits beside us. His mind work stands before us as his monument. Every sphere of American scientific activity has been tonched by him, and he has prepared these wonderful laboratories to give back from their outcome to those who have served him. The engineers in science, the whole world over, have contributed to what you find here. It is a monument to scientific Cincinnati, an honor to our people

Now just a word concerning the American Chemical Society An old man in the art, some call me, because $I$ go back in study and research before there was any American Chemical Society. But in the way of reminiscences, I am not the only old man here. We have with us Dr. Alfred Springer, who can tell you better than can 1 , the story of the farst meeting of the Cincinnati Chemical Society, which long antedated the birth of the American Chemical Society. The first meeting of the Cincinnati Society was called by him, at his home. The second meeting, at which the name "The Cincinnati Chemical Society" was adopted, was held at the home of Mr. Rheum, over his drug

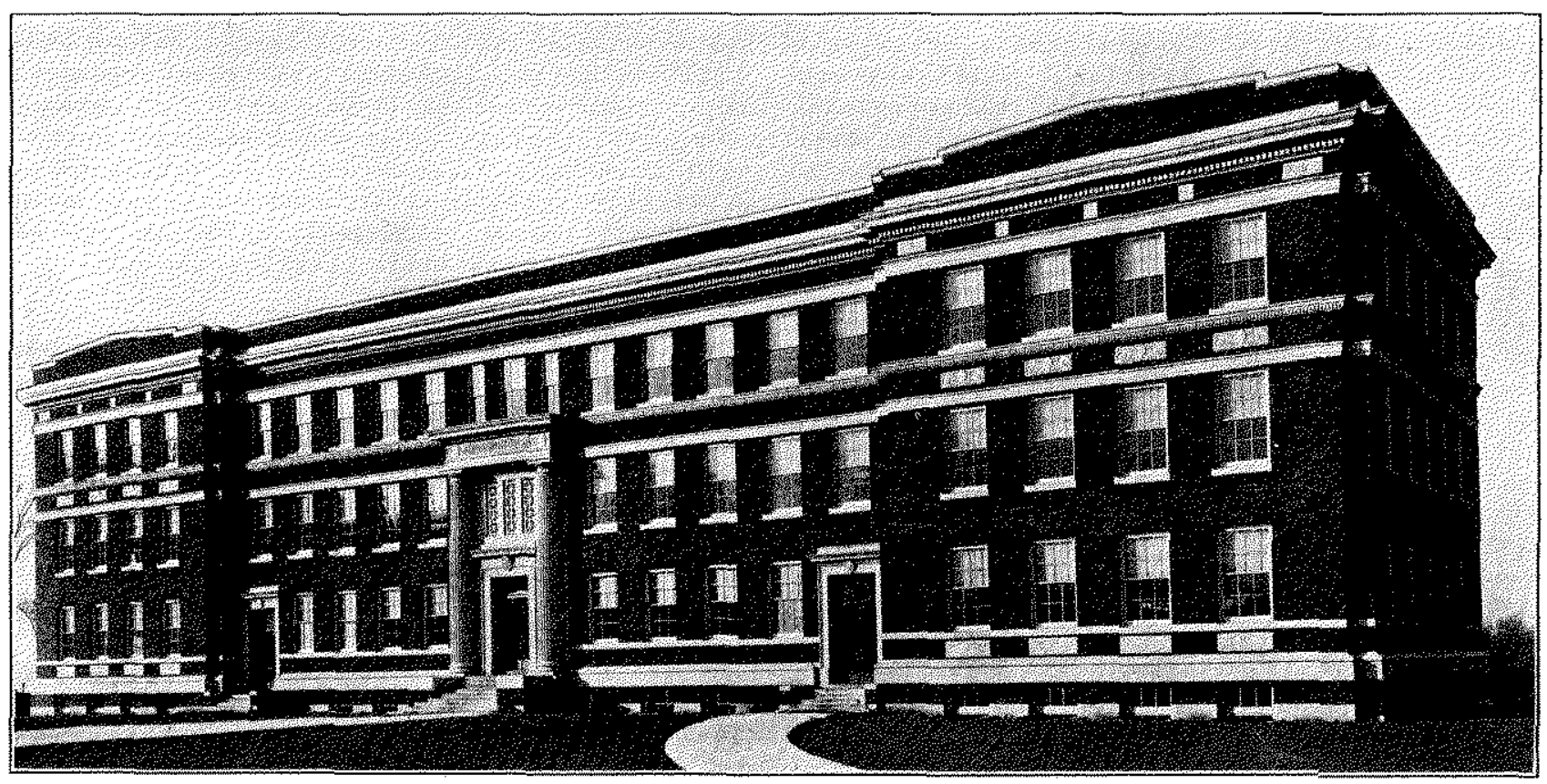

CramMCA, LABORATORY, UNIVERSITY OF CWNCINNATI

to go to Syria, and Dr. Norton gave up his place to his first assistant. Dr. Thomas Evvans. He, too, did well his work, but, unfortunately, was taken away from us, in the very strength of his life. But such work as his could no more die than does the redwood tree when it falls to earth, leaving its life seed to become a new tree.

Came then our good friend, Professor Jones, and I must tell you something about the commencement of the chemical department of the building into which he went. When it was first buil, there were so few students in that department that one day, as we stood in its uncompleted rooms, Norton said, "lioyd, I wonder if it will ever be filled with a class. Haven"t we bitten off more than we can chew? In other words, shall I not be criticized for spending so much money on a laboratory?" He did not foresee the stupendous growth that would so soon be accomplished.

Came finally Dr. Dabney, a President so competent to study men, and to put the right man in the right place. The Chemical Department that Norton leit might never be filled, grew until the students could not get into it. When you go from this store, Fifth and Broadway. Subsequent meetings were held in the Ohio Mechanics Institute. When the time came at last for the organization of an American Chemical Society, we naturally became the first section of that society in this part of the West. To attend our meetings, came chemists from Columbus, Indianapolis, Lexington, and other cities round about.

I have presented but a superficial idea of that which comes to us from this great building. "Remember now thy Creator in the days of thy youth." We are to day in our youth, as concerns chemistry. We are but pioneers, struggling, as I believe, over a by-path that leads to unseen avenues. Our path till now has been stony. Who can foresee what will develop to-morrow?

I hold in my hands a slip of paper on which is written, in substance: Three years ago, Cincinnati entertained the American Chemical Society. In order that proper attention might be given to visitors at this meeting, a collection was taken, and a committee appointed, who were given authority to spend all they needed. We took care of our visitors, to their apparent 


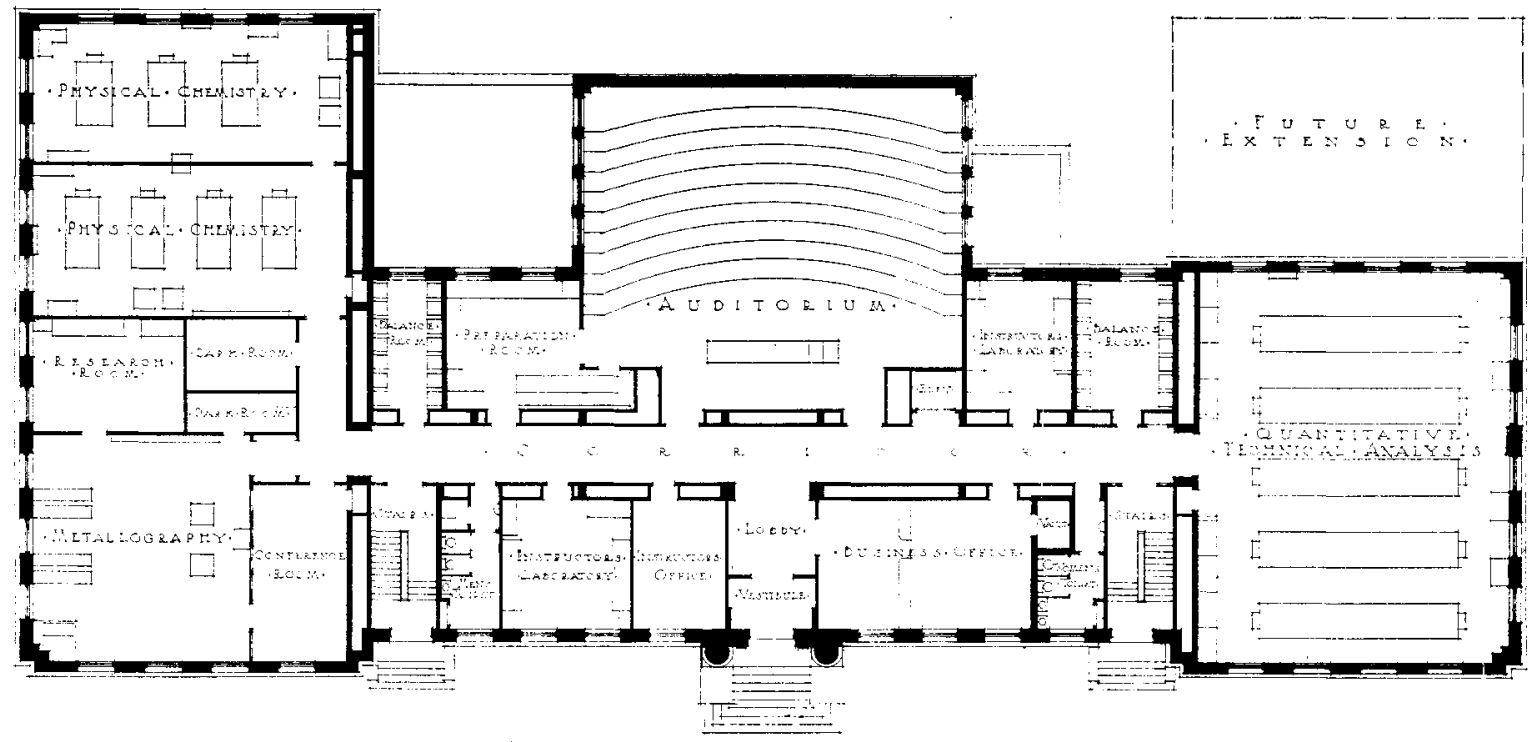

First Floor Plan, University of Cincinati

satisfaction. After all the bills were paid, a fund of \$1500 was left. To whom did this belong? It had been contributed for a special purpose, which had been accomplished. It was decided, after much consultation, that this fund should form a nucleus to help needy young people who wished to attend the Chemical Department, and who would "make good" in life if given an opportunity. It was decided that this money be loaned them, the principal and interest to be returned to the University when in later years they were enabled to do so, through the equipment they had received. Can a more important fund be established than this? Is the equipping of these young people to be good citizens and so situated as to care for the interests of their country, not an opportunity? I will take the liberty of reading the names of four of those who by their contributions have increased this fund to the sum of $\$ 2,000$. These are Dr. Ernst Twitchell, Dr. F. W. Weissmann, Mr. Robert Hochstetter, and the firm of Ault and Wiborg. May I not be permitted to predict that those who can help this fund in the city of Cincinnati will be surprised, fifty years from now, to know what this nest egg has accomplished?

As a closing thought, may I not be personal? Much do I appreciate the opportunity of speaking here to-day. To appear on the same platform with the learned men of this great University, including its President, to know that I am listened to by Dr. Herty, past president of the American Chemical Society, to be introduced by Judge Rufus B. Smith, of the Board of Trustees, and to speak to an audience made up of intellectual Cincinnati, is indeed an honor that anyone might well hold precious.

\section{THE SWING OF THE PENDULUM IN CHEMISTRY}

\section{By Chartes H. Herty}

It is a peculiar pleasure to be present on this occasion which marks the formal opening of the new Chemical Laboratory of the University of Cincinnati. Too often of late have we read of loss by fire of historic laboratories; too often have we heard the lament of laboratories overcrowded with students. Here brick and mortar have been promptly joined and a fine housing given to the splendid corps of instructors whose work and whose policies have given to this institution as high rank in chemistry as developed in America. Here, too, has been happily worked out a combination of devotion to the advancement of chemistry as a science and to the application of chemistry in the service of mankind.

The erection of this building gives heart to the hope that the pendulum which has swung so strongly during the past two and a half years towards the development of the chemical industries, is now about to begin an equally strong swing towards the betterment of conditions in our Universities-a betterment which should manifest itself in greater laboratory space and better equipment, in higher salaries for the teaching staff and in such increased number of instructors as will make possible more time for research. If the pendulum does not begin soon to swing strongly in this direction there is danger ahead.

\section{CONDITIONS UP TO IOI 4}

Up to the outbreak of the present great war the chemists of America had been working quietly but with zeal and effectiveness in university laboratories until we had reached the point where no longer was it considered necessary to go abroad to receive thorough and inspiring training in chemical research. This fact had not been widely advertised but it was evidenced by the constant increase in the proportion of young men receiving their higher training in the universities of this country, and by the constantly increasing prestige of the chemical journals. of America.

So, too, in the industries of America, chemists had been busily and successfully engaged in solving the many problems of those industries which, because of our resources and environment, were of primary importance. Corn, the great staple of the Middle West, had been converted into a host of useful substances, through the transforming agency of our chemists. Cottonseed, so long neglected in the southern states, had become the raw material of a great industry whose output now approaches in value that of the lint column which for many years had alone given value to the cotton crop. The advances in metallurgy furnished brilliant examples of skill, ingenuity and sound chemical development. Petroleum refining had made possible the tremendous development of the automobile and allied industries. The tanning of leather had been placed upon surer foundations. The great industries of the heavy chemicals, acids, alkalies, etc., received a development of such consummate skill and magnitude of output as to assure success in other lines. At Niagara Falls an electrochemical industry was founded which stands to-day the greatest of its kind in the world, the products of this group now constituting essential equipment of many industries throughout the nation, and assuring us a degree of national preparedness, whose importance no one can overestimate in the great war into which we are entering. These are only a few illustrations of the many-sided and successful efforts of the industrial chemists previous to the outbreak of the present war. 